\title{
3. OPODATKOWANIE KRYPTOWALUT W WYBRANYCH KRAJACH ŚWIATA
}

\author{
Maciej Szczepkowski \\ Uniwersytet Ekonomiczny w Poznaniu \\ maciej.szczepkowski@ue.poznan.pl \\ https://doi.org/10.18559/978-83-8211-083-8/3
}

\section{Taxation of cryptocurrencies in selected countries of the world}

\begin{abstract}
Like any innovation, a virtual currency raises the question whether national tax systems are prepared for it. As a part of this study, the current areas of research that academics deal with in the context of the cryptocurrency market in Poland and in the world are presented. In addition, the issues of taxation of cryptocurrency transactions in developed countries, such as Germany, the United States and Japan according to the legal status for the fiscal year 2021, are discussed. The article also presents a summary of the most important solutions in force from 2019 regarding the taxation of cryptocurrencies in the field of income tax in Poland. The study is based on current literature and tax acts.
\end{abstract}

Keywords: bitcoin, cryptocurrencies, taxation, harmonization, income tax.

\subsection{Wstęp}

W 2021 roku przypada już trzynasta rocznica powstania pierwszej zdecentralizowanej wirtualnej waluty wykorzystującej technologię blockchain, czyli stworzonej przez Satoshi'ego Nakamoto kryptowaluty bitcoin. Wówczas zapewne mało kto mógłby przewidzieć, że to, co uważano za elektroniczny system płatności oparty na dowodach kryptograficznych, stanie się jedną z większych innowacji XXI wieku. W ostatnich latach można zaobserwować dynamiczny rozwój rynku kryptowalut. Jak każda innowacja, wirtualna waluta rodzi pytanie, czy systemy podatkowe państw są na nią przygotowane.

W tym rozdziale przedstawiono bieżące obszary badań, którymi zajmują się naukowcy w kontekście rynku kryptowalut w Polsce i na świecie. Ponadto poruszono kwestie opodatkowania transakcji kryptowalutowych w krajach rozwiniętych, tj. w Stanach Zjednoczonych, Japonii i Niemczech, według stanu prawnego na rok podatkowy 2021. Zaprezentowano też zestawienie najważniejszych rozwiązań

Sugerowane cytowanie:

Szczepkowski, M. (2021). Opodatkowanie kryptowalut w wybranych krajach świata. W: K. Perez (red.), Innowacje finansowe $w$ gospodarce 4.0 (s. 51-69). Poznań: Wydawnictwo Uniwersytetu Ekonomicznego w Poznaniu. https://doi.org/ 10.18559/978-83-8211-083-8/3 
obowiązujących od 2019 roku, dotyczących opodatkowania kryptowalut w zakresie podatku dochodowego w Polsce. Jako podsumowanie rozważań przeprowadzono również analizę SWOT obecnie funkcjonującego systemu opodatkowania kryptowalut na świecie, wskazując na jego mocne i słabe strony oraz szanse i zagrożenia. Opracowanie oparto na analizie literatury przedmiotu oraz przepisów ustaw podatkowych.

\subsection{Geneza i rynek kryptowalut}

Najpopularniejszą spośród kilku tysięcy dostępnych dziś kryptowalut jest bitcoin, który jest kojarzony zdecydowanie najczęściej, kiedy w publicznej dyskusji pojawia się słowo „kryptowaluta”. Choć bitcoin powszechnie uważany jest za pierwszą kryptowalutę, to już wcześniej podjęto próbę wprowadzenia podobnego rozwiązania. W 1982 roku David Chaum miał pomysł na anonimowe przelewy, stworzył nawet swój koncept „Blind signatures for untraceable payments", a następnie opublikował go na wydziale informatyki Uniwersytetu Kalifornijskiego. Po kilku latach założył własną działalność. Wykorzystując swoje pomysły, stworzył elektroniczny system DigiCash umożliwiający przelewy między użytkownikami. Użytkownicy uruchomiali na komputerach oficjalny program, doładowywali konta za pomocą przelewów z banków, ale tylko tych, które wspierały ten system. Wysłana prawdziwa waluta po przetworzeniu przez system stawała się w programie „cyberdolarami”. Jak zakładano, transakcje były anonimowe. System DigiCash był jednak scentralizowany, przez co podatny na ataki hakerskie. Firma Chauma miała zarabiać na licencjonowaniu technologii, ale już w 1998 roku zbankrutowała (Pitta, 1999). W 2008 roku, kiedy trwał kryzys finansowy, prezydent Stanów Zjednoczonych G.W. Bush podpisał ustawę o ratowaniu sektora finansowego, zwaną planem Paulsona. Ustawa zakładająca przeznaczenie na ten cel 700 mld dolarów pochodzących z podatków uratowała kilku nieuczciwych bankierów, co nie spodobało się między innymi twórcy bitcoina podającego się w internecie za Satoshim Nakamoto, który w swoim artykule Bitcoin: A peer-to-peer electronic cash system wyjaśnił istotę funkcjonowania bitcoina (Markowski, 2019, s.71).

W posiadanie bitcoina można wejść na trzy sposoby: wydobycie, zakup lub akceptację płatności. Wydobycie bitcoina to inaczej rozwiązywanie ,zagadek matematycznych", a właściwie szyfrowanie bloku polegające na odnalezieniu odpowiedniego formatu szyfru. Jest to możliwe dzięki specjalistycznym komputerom o wysokiej mocy obliczeniowej, zwanych koparkami, i jest dokonywane 
przez tzw. górników (Perez i Urbaniak, 2013, s. 165-167). Zaprojektowana przez twórców kryptowaluty architektura umożliwia emisję 21000000 BTC. Za każde rozwiązanie jednego bloku kryptograficznego „górnik” otrzymuje nagrodę, która co 210000 rozwiązanych bloków zmniejsza się o połowę. Na początku za rozwiązanie jednego bloku płacono 50 BTC, następnie 25 BTC. Obecnie produkcja 1 bloku w sieci bitcoin zajmuje10 minut, co jest nagradzane 6250 BTC. Dziennie wydobywa się około 900 BTC. Według najnowszych analiz szacuje się, że w kwietniu 2024 roku nagroda spadnie o połowę, do 3125 BTC. Do tej pory wykopano około $18,6 \mathrm{mln}$ BTC (88,57\% z $21 \mathrm{mln}$ BTC). To oznacza, że do wykopania pozostało około $2,4 \mathrm{mln}$ BTC, a zgodnie z prognozami powinno to zająć aż 119 lat. Rok 2140 to $\mathrm{w}$ tej chwili prognozowany rok wykopania ostatniego BTC (Rosik, 2021). Drugim sposobem stania się posiadaczem bitcoina jest jego zakup. Jest on dostępny w kantorach, na giełdach internetowych (na przykład bitbay.net) lub na wolnym rynku. Ostatni sposób to akceptacja płatności w BTC. Dla fanów kryptowaluty powstała specjalna mapa (coinmap.org), na której na bieżąco umieszczane są wszystkie punkty usługowe na świecie akceptujące płatność bitcoinem. Według danych z czerwca 2021 roku było 22290 lokalizacji, z czego kilkadziesiąt znajduje się w Polsce - najwięcej w Warszawie (47 punktów; por. rysunek 3.1). Wirtualną walutę akceptują takie globalne tuzy, jak Dell, Microsoft i Wikipedia. W Polsce bitconem można zapłacić za usługę w szpitalu Medicover i doładowanie telefonu na kartę w T-Mobile oraz Heyah. Za wirtualny pieniądz można zakupić także hamburgera w Bobby Burger czy kawę w MiTo art café books (Fryc, 2016).

Według danych z czerwca 2021 roku na portalu investing.com można śledzić notowania blisko 6 tysięcy kryptowalut (dokładnie 5861). Według wartości ich kapitalizacji do najpopularniejszych poza bitcoinem należą ethernum, tether, binance coin czy cardano. Ich kapitalizacja w każdym z przypadków przekracza $45 \mathrm{mld}$ USD (Investing.com, 2021). Do największych i najbardziej popularnych giełd zajmujących się handlem kryptowalutami należą: Binance (zdecydowanie największa i najpopularniejsza platforma, powstała w Szanghaju w 2017 roku, a obecnie jej siedziba mieści się na Malcie; oferuje swoim klientom prawie 200 kryptowalut), CoinBene (pod kątem klasycznych obrotów samej wymiany Bitcoin to obecnie największa giełda kryptowalutowa; to chińska platforma handlu założona w 2017 roku, gdzie do dyspozycji klientów jest 150 kryptowalut, a wysokie wolumeny pozwalają zachować dobrą płynność handlu) oraz Kraken (to amerykańska giełda kryptowalut, która powstała w 2011 roku w San Francisco; oferuje stosunkowo małą liczbę kryptowalut, ale koncentruje się na ich jakości) (Bandura, 2021) (rysunek 3.1). 


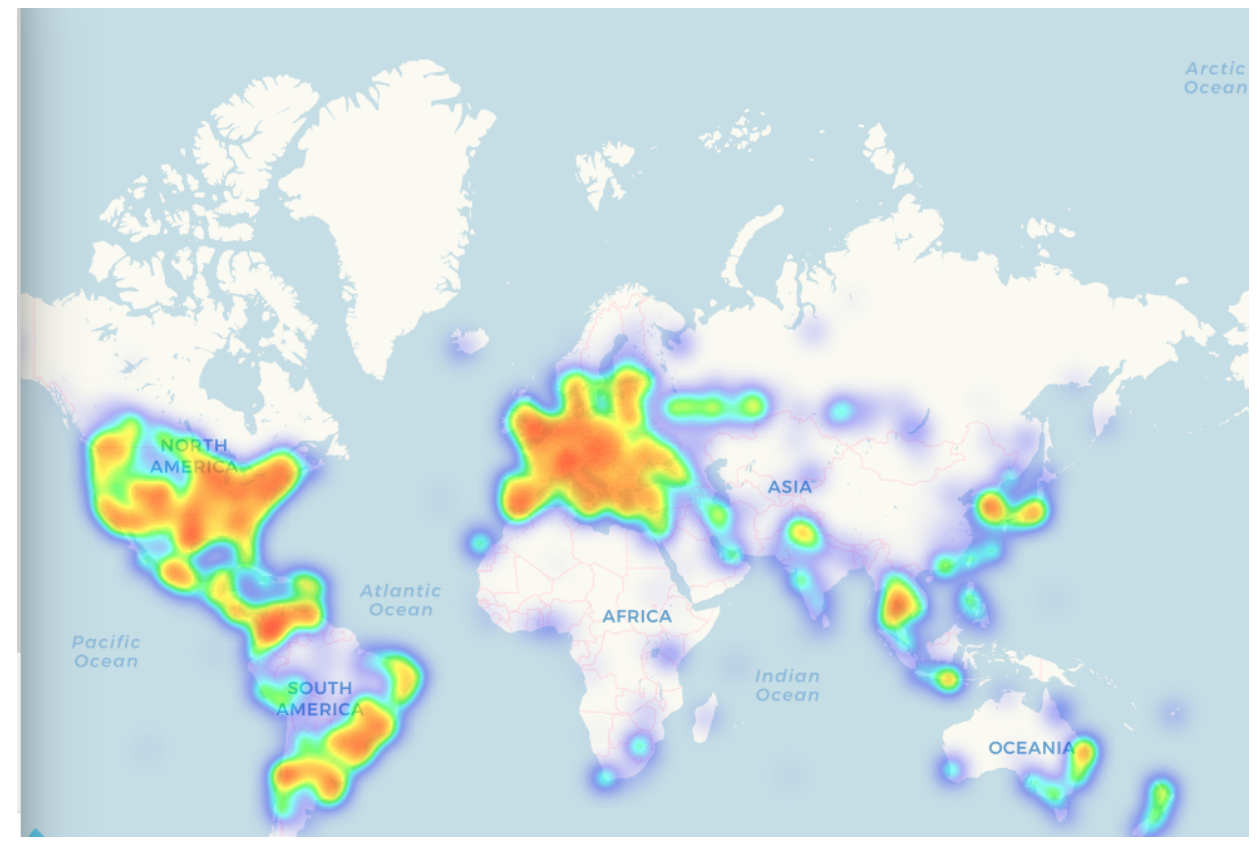

Rysunek 3.1. Mapa dostępu płatności za pomocą bitcoina na świecie (stan na czerwiec 2021) Źródło: (Coinmap.org).

Bitcoin oraz inne kryptowaluty budzą spore zainteresowanie zarówno wśród inwestorów, co jest zrozumiałe i w znacznej mierze spowodowane gwałtownym wzrostem ich cen. W ślad za tym zainteresowanie kryptowalutami wykazują też naukowcy. W samym tylko 2020 roku bitcoina rozpatrywano naukowo jako bezpieczną inwestycję w czasie zawirowań gospodarczych w okresie pandemii COVID-19, a także zajmowano się rynkiem kryptowalut z punktu widzenia jego kontroli oraz opodatkowania. W tabeli 3.1 zaprezentowano wyniki wybranych badań w tych obszarach.

Zainteresowanie tematyką bitcoina i kryptowalut jest również bardzo widoczne w licznych publikacjach polskich naukowców. Prace te dotyczą między innymi: próby wskazania perspektyw rozwoju kryptowalut, płynności rynku wymiany walut wirtualnych czy perspektywy wykorzystania rozwiązań typu blockchain w sektorze publicznym. Otrzymane wyniki w sposób syntetyczny zaprezentowano w tabeli 3.2. 
Tabela 3.1. Wybrane badania w obszarze kryptowalut - autorzy zagraniczni

\begin{tabular}{|c|c|c|c|}
\hline Autorzy & \begin{tabular}{|c|} 
Rok \\
publikacji
\end{tabular} & Tematyka badań & Wnioski \\
\hline $\begin{array}{l}\text { Thomas Conlon, } \\
\text { Richard McGee }\end{array}$ & 2020 & $\begin{array}{l}\text { Czy bitcoina moż- } \\
\text { na traktować jako } \\
\text { bezpieczną przystań } \\
\text { w czasie pandemii } \\
\text { COVID-19? }\end{array}$ & $\begin{array}{l}\text { Bitcoin nie działa jako bezpieczna } \\
\text { przystań }\end{array}$ \\
\hline $\begin{array}{l}\text { Chi-Wei Su, Meng } \\
\text { Qin, Ran Tao, Mu- } \\
\text { hammad Umar }\end{array}$ & 2020 & $\begin{array}{l}\text { Czy bitcoin może } \\
\text { poprawić perspek- } \\
\text { tywy inwestycji } \\
\text { energetycznych? }\end{array}$ & $\begin{array}{l}\text { Pęknięcie bańki bitcoina osłabiło jego } \\
\text { zdolność hedgingową, popytowi na ropę } \\
\text { zagraża rosnąca cena bitcoina }\end{array}$ \\
\hline \begin{tabular}{|l|} 
Chi-Wei Su, Meng \\
Qin, Ran Tao, \\
Xue-Feng Shao, \\
Lucian Liviu \\
Albu, Muhammad \\
Umar
\end{tabular} & 2020 & $\begin{array}{l}\text { Czy bitcoin może za- } \\
\text { bezpieczyć się przed } \\
\text { ryzykiem wydarzeń } \\
\text { geopolitycznych? }\end{array}$ & $\begin{array}{l}\text { Rynek bitcoina jest głównym wskaźni- } \\
\text { kiem do bardziej kompleksowej analizy } \\
\text { globalnego otoczenia geopolitycznego }\end{array}$ \\
\hline \begin{tabular}{|l|} 
Syed Jawad Hus- \\
sain Shahzad, \\
Elie Bouri, David \\
Roubaud, Ladislav \\
Kristoufek
\end{tabular} & 2020 & $\begin{array}{l}\text { Bezpieczna przystań, } \\
\text { hedging i dywersy- } \\
\text { fikacja dla rynków } \\
\text { akcji G7: złoto kontra } \\
\text { bitcoin }\end{array}$ & $\begin{array}{l}\text { Złoto jest niekwestionowaną bezpieczną } \\
\text { przystanią i zabezpieczeniem dla kilku } \\
\text { indeksów giełdowych w gospodarkach } \\
\text { grupy G7. Bitcoin pełni te funkcje } \\
\text { w Kanadzie. Korzyści z dywersyfikacji } \\
\text { oferowane przez złoto są wyższe niż } \\
\text { w przypadku bitcoina }\end{array}$ \\
\hline $\begin{array}{l}\text { John M. Griffin, } \\
\text { Amin Shams }\end{array}$ & 2020 & $\begin{array}{l}\text { Bitcoin jako waluta } \\
\text { niekontrolowana }\end{array}$ & $\begin{array}{l}\text { Waluty wirtualne zaprojektowane w celu } \\
\text { ominięcia tradycyjnych systemów ban- } \\
\text { kowych nie wyeliminowały potrzeby } \\
\text { zewnętrznego nadzoru, monitorowania } \\
\text { i ram regulacyjnych }\end{array}$ \\
\hline $\begin{array}{l}\text { Michael D. Cha- } \\
\text { tham, Thomas } \\
\text { K. Duncan }\end{array}$ & 2020 & $\begin{array}{l}\text { Opodatkowanie jako } \\
\text { bariera rozwoju tech- } \\
\text { nologii blockchain }\end{array}$ & $\begin{array}{l}\text { Żmudna ewidencja może zniechęcić do } \\
\text { inwestowania zasobów w dalszy rozwój } \\
\text { technologii blockchain. Poprzez skom- } \\
\text { plikowany system podatkowy władza } \\
\text { publiczna naraża się na znaczne uszczu- } \\
\text { plenie utracie dochodów podatkowych }\end{array}$ \\
\hline $\begin{array}{l}\text { Stefan } \\
\text { Scharnowski }\end{array}$ & 2021 & $\begin{array}{l}\text { Płynność bitcoina } \\
\text { i jej derminanty }\end{array}$ & $\begin{array}{l}\text { W ostatnich latach bardzo poprawiła się } \\
\text { płynność na rynku bitcoina. Zmienność } \\
\text { cen złota jest powiązana z wahaniami } \\
\text { cen bitcoina }\end{array}$ \\
\hline $\begin{array}{l}\text { Wei Chen, Huilin } \\
\text { Xu, Lifen Jia, } \\
\text { Ying Gao }\end{array}$ & 2021 & $\begin{array}{l}\text { Wykorzystanie } \\
\text { modelu uczenia } \\
\text { maszynowego do } \\
\text { prognozowania kursu } \\
\text { bitcoina }\end{array}$ & $\begin{array}{l}\text { Uwarunkowania ekonomiczne i techno- } \\
\text { logiczne są ważniejsze dla przewidywa- } \\
\text { nia kursu bitcoina niż historyczny kurs } \\
\text { tej kryptowaluty }\end{array}$ \\
\hline
\end{tabular}


Tabela $3.1-\mathrm{cd}$

\begin{tabular}{|l|c|l|l|}
\hline \multicolumn{1}{|c|}{ Autorzy } & $\begin{array}{c}\text { Rok } \\
\text { publikacji }\end{array}$ & \multicolumn{1}{|c|}{ Tematyka badań } & \multicolumn{1}{c|}{ Wnioski } \\
\hline $\begin{array}{l}\text { Dominique } \\
\text { Guégan i Thomas } \\
\text { Renault }\end{array}$ & 2021 & $\begin{array}{l}\text { Czy nastroje inwe- } \\
\text { storów w mediach } \\
\text { społecznościowych } \\
\text { dostarczają solidnych } \\
\text { informacji na temat } \\
\text { prognozowania stóp } \\
\text { zwrotu z bitcoina? }\end{array}$ & $\begin{array}{l}\text { W okresie tzw. „bańki cenowej” istnieje } \\
\text { statystycznie istotna zależność między } \\
\text { nastrojem inwestorów a zwrotami z bit- } \\
\text { coina dla częstotliwości do 15 minut }\end{array}$ \\
\hline
\end{tabular}

Źródło: opracowanie własne na podstawie przytoczonej literatury.

Tabela 3.2. Wybrane badania w obszarze kryptowalut - autorzy krajowi

\begin{tabular}{|l|c|l|l|}
\hline \multicolumn{1}{|c|}{ Autorzy } & $\begin{array}{c}\text { Rok } \\
\text { publikacji }\end{array}$ & Tematyka badań & \multicolumn{1}{|c|}{ Wnioski } \\
\hline $\begin{array}{l}\text { Janusz Brzeszczyń- } \\
\text { ski, Jerzy Gajdka, } \\
\text { Tomasz Schabek }\end{array}$ & 2020 & $\begin{array}{l}\text { Bitcoin jako nowa } \\
\text { waluta }\end{array}$ & $\begin{array}{l}\text { Bitcoin nie spełnia kryteriów, które po- } \\
\text { winny spełniać waluty. } \\
\text { Kurs bitcoina jest bardzo słabo powiąza- } \\
\text { ny z kursami walut tradycyjnych, które } \\
\text { z kolei są ze sobą mocno skorelowane. } \\
\text { Cena bitcoina nie zmienia się w odpo- } \\
\text { wiedzi na publikacje nowych danych } \\
\text { makroekonomicznych }\end{array}$ \\
\hline Paweł Marszałek & 2019 & $\begin{array}{l}\text { Kryptowalu- } \\
\text { ty - pojęcie, cechy, } \\
\text { kontrowersje }\end{array}$ & $\begin{array}{l}\text { Jest za wcześnie, by można było uznać } \\
\text { kryptowaluty za pieniądz. } \\
\text { Ujednolicenie rozwiązań w sferze } \\
\text { kryptowalut przyniesie korzyści dla } \\
\text { zwolenników i przeciwników walut } \\
\text { wirtualnych }\end{array}$ \\
\hline Katarzyna Włosik & 2019 & $\begin{array}{l}\text { Porównanie wybra- } \\
\text { nych giełd krypto- } \\
\text { walut pod względem } \\
\text { płynności }\end{array}$ & $\begin{array}{l}\text { Platforma, która znajduje się wśród } \\
\text { globalnych liderów w obrocie bitcoinem } \\
\text { w danej walucie tradycyjnej, może być } \\
\text { postrzegana jako podmiot mały, jeśli } \\
\text { zostanie wzięty pod uwagę obrót w in- } \\
\text { nej walucie tradycyjnej }\end{array}$ \\
\hline Andrzej Sławiński & 2020 & $\begin{array}{l}\text { Czy technologie } \\
\text { IT i globalizacja } \\
\text { zmienią mechanizm } \\
\text { kreacji pieniądza? }\end{array}$ & $\begin{array}{l}\text { Kryptowaluty będą musiały przejść dłu- } \\
\text { gą ewolucję, zanim będą miały szansę } \\
\text { stać się integralną częścią systemów } \\
\text { monetarnych, zamiast być aktywami } \\
\text { czysto spekulacyjnymi }\end{array}$ \\
\hline
\end{tabular}


Tabela $3.2-$ cd.

\begin{tabular}{|l|c|l|l|}
\hline \multicolumn{1}{|c|}{ Autorzy } & $\begin{array}{c}\text { Rok } \\
\text { publikacji }\end{array}$ & \multicolumn{1}{|c|}{ Tematyka badań } & \multicolumn{1}{|c|}{ Wnioski } \\
\hline $\begin{array}{l}\text { Marcin Kowal- } \\
\text { czyk, Dominik } \\
\text { Wilga }\end{array}$ & 2019 & $\begin{array}{l}\text { Perspektywa rozwo- } \\
\text { ju technologii block- } \\
\text { chain w sektorze } \\
\text { publicznym }\end{array}$ & $\begin{array}{l}\text { Tego typu rozwiązania mogą być uży- } \\
\text { wane przez środowiska przestępcze. } \\
\text { Wykorzystanie tego typu rozwiązań } \\
\text { w sektorze publicznym byłoby nie- } \\
\text { zgodne z założeniami oddolnego ruchu } \\
\text { kryptologów tworzących założenia teo- } \\
\text { retyczne sieci rozproszonego zaufania }\end{array}$ \\
\hline $\begin{array}{l}\text { Barbara Będow- } \\
\text { ska-Sójka i Agata } \\
\text { Kliber }\end{array}$ & 2021 & $\begin{array}{l}\text { Czy istnieje jedna } \\
\text { bezpieczna przystań } \\
\text { w przypadku róż- } \\
\text { nych turbulencji? } \\
\text { Przykłady złota, bit- } \\
\text { coina i ethera }\end{array}$ & $\begin{array}{l}\text { Tylko złoto mogło być postrzegane } \\
\text { jako silna, bezpieczna przystań podczas } \\
\text { wszystkich turbulencji, z wyjątkiem } \\
\text { COVID. Czasami kryptowaluty mogą } \\
\text { odgrywać rolę słabych bezpiecznych } \\
\text { przystani na rynku europejskim }\end{array}$ \\
\hline $\begin{array}{l}\text { Barbara Będow- } \\
\text { ska- Sójka, Tomasz } \\
\text { Hinc i Agata Kliber }\end{array}$ & 2020 & $\begin{array}{l}\text { Zmienność i płyn- } \\
\text { ność na rynkach } \\
\text { kryptowalut }\end{array}$ & $\begin{array}{l}\text { Duża zmienność przyciąga inwestorów } \\
\text { i powoduje większe zainteresowanie } \\
\text { nowymi instrumentami finansowymi }\end{array}$ \\
\hline
\end{tabular}

Źródło: Opracowanie własne na podstawie przytoczonej literatury.

\subsection{Opodatkowanie transakcji kryptowalutowych w wybranych krajach świata}

W zależności od regionu świata podejście do opodatkowania transakcji kryptowalutowych może być zgoła różne, a harmonizacja tych systemów może potrwać jeszcze wiele lat. $\mathrm{W}$ tym rozdziale autor postanowił przeanalizować podstawowe zasady opodatkowania walut wirtualnych wśród najbardziej rozwiniętych gospodarek świata na trzech różnych kontynentach: w Ameryce Północnej (Stany Zjednoczone), Azji (Japonia) i Europie (Niemcy). Następnie przedstawiono, jak na tym tle wyglądają rozwiązania stosowane w Polsce, gdzie także w ostatnich latach udoskonala się zasady podatkowe dotyczące transakcji kryptowalutowych. Nie zaprezentowano tu stanowiska Unii Europejskiej w tej sprawie, ponieważ wśród polityków państw UE opodatkowanie kryptowalut jest nadal ważnym obszarem do dyskusji i potencjalnego współdziałania bez ostatecznych rozstrzygnięć.

\section{Niemcy}

Zgodnie z prawodawstwem w Republice Federalnej Niemiec kryptowaluty nie są prawnym środkiem płatniczym. W związku z tym dochodów osiągniętych $\mathrm{z}$ ich 
sprzedaży nie można porównywać $\mathrm{z}$ dochodami z akcji, inwestycji lub innych transakcji finansowych. Zgodnie z interpretacjami wydawanymi przez organy skarbowe w Niemczech dochody $z$ handlu kryptowalutami są porównywalne $\mathrm{z}$ dochodami z dzieł sztuki czy innych kosztowności. Dzięki temu zyski ze sprzedaży walut cyfrowych mogą w niektórych przypadkach być wolne od podatku. Jest to zależne od:

- dochodu lub zysku uzyskanego ze sprzedaży kryptowalut,

- okresu posiadania przez podatnika kryptowalut (TaxFix, 2021).

W sytuacji kiedy podatnik posiada kryptowalutę przez dłużej niż rok, sprzedaż jest wolna od podatku niezależnie od osiągniętego dochodu. Co więcej, nie ma obowiązku deklarowania tego typu zysków w zeznaniu podatkowym. W przypadku gdy kryptowaluty są sprzedawane po okresie krótszym niż 12 miesięcy od daty ich zakupu, od podatku są zwolnione zyski w kwocie nieprzekraczającej 600 euro. Należy jednak pamiętać, że gdy zysk będzie wyższy niż 600 euro, wówczas podatnik jest zobligowany, aby opłacić podatek od całej kwoty osiągniętego dochodu (Einkommensteuergesetz, 2020, § 23, ust. 3). Podatnicy, którzy realizują transakcje kryptowalutowe regularnie, mogą mieć problem z określeniem dokładnego okresu przechowywania kryptowaluty. Wówczas istnieje możliwość zastosowania metody FIFO i LIFO (Einkommensteuergesetz, 2020, § 23, ust. 1, pkt 2, zdanie 3). Zdecydowanie bardziej przyjazna wydaje się metoda FIFO, która pozwala na prowadzenie szczegółowego rejestru transakcji. Aby obliczyć dochód, należy cenę sprzedaży pomniejszyć o koszt nabycia oraz koszty transakcyjne. Jeżeli w wyniku transakcji podatnik ponosi stratę, może pomniejszyć o jej wysokość swoje zobowiązanie podatkowe wynikające z prywatnych transakcji sprzedaży takich jak dzieł sztuki czy kosztowności. Jeżeli podatnik nie osiągnął żadnych zysków, ma możliwość przeniesienia swoich strat bez ograniczeń na przyszłe lata i skompensować je przyszłymi zyskami. W Niemczech tego rodzaju sprzedaż jest opodatkowana podatkiem dochodowym od osób fizycznych, daniną solidarnościową oraz w niektórych przypadkach także podatkiem kościelnym (De Hoon, 2021). Stawki podatku dochodowego w Niemczech według stanu na rok podatkowy 2021 przedstawia tabela 3.3.

Tabela 3.3. Opodatkowanie transakcji kryptowalutowych w Niemczech w 2021 roku

\begin{tabular}{|l|c|}
\hline \multicolumn{1}{|c|}{ Dochód } & Stawka podatkowa \\
\hline Poniżej 9408 EUR & 0 \\
\hline 9409 EUR - 57 051 EUR & 14 \\
\hline 57 052 EUR - 270 500 EUR & 42 \\
\hline Powyżej 270 501 EUR & 45 \\
\hline
\end{tabular}

Źródło: (Ustawa z dnia 8 października 2009). 


\section{Stany Zjednoczone}

W Stanach Zjednoczonych kryptowaluty podlegają opodatkowaniu podatkiem od zysków kapitałowych (capital gains tax) oraz podatkiem dochodowym (income tax). W przypadku podatku od zysków kapitałowych są to:

- sprzedaż kryptowaluty za walutę tradycyjną,

- wykorzystanie kryptowaluty do zakupu towarów i usług,

- handel lub zamiana jednego zasobu kryptograficznego na inny, na giełdzie lub bezpośrednio w trybie peer-to-peer.

W przypadku podatku dochodowego opodatkowaniu podlegają:

- wynagrodzenie za pracę wypłacone kryptowalutą,

- dochód osiągnięty z „kopania” kryptowalut i opłat transakcyjnych,

- wszelkie zyski z odsetek od kryptowalut z pożyczek zdecentralizowanych.

W Stanach Zjednoczonych zobowiązanie podatkowe od zysków kapitałowych jest zależne od tego, jak długo podatnik trzyma swoje aktywa i w jakim przedziale podatkowym znajduje się osiągnięty przez niego dochód. W przypadku aktywów posiadanych krócej niż rok wszelkie zyski są opodatkowane według stawek właściwych dla podatku dochodowego (Leech, 2021). Stawki podatkowe obowiązujące w 2021 roku przedstawia tabela 3.4.

Tabela 3.4. Stawki podatku dochodowego w USA na 2021 rok

\begin{tabular}{|c|c|c|c|c|}
\hline $\begin{array}{c}\text { Status / } \\
\text { Stawka } \\
(\%)\end{array}$ & $\begin{array}{c}\text { Rozliczenie } \\
\text { samodzielne } \\
\mathbf{( \$ )}\end{array}$ & $\begin{array}{c}\text { Rozliczenie wspólne } \\
\mathbf{z} \text { małżonkiem } \\
\mathbf{( \$ )}\end{array}$ & $\begin{array}{c}\text { Małżonkowie } \\
\text { rozliczający się } \\
\text { osobno } \\
\mathbf{( \$ )}\end{array}$ & $\begin{array}{c}\text { Głowa rodziny } \\
\mathbf{( \$ )}\end{array}$ \\
\hline 10 & do 9 950 & do 19 900 & do 9 950 & do 14 200 \\
\hline 12 & $9951-40525$ & $19901-81050$ & $9951-40525$ & $14201-54200$ \\
\hline 22 & $40526-86375$ & $81051-172750$ & $40526-86375$ & $54201-86350$ \\
\hline 24 & $86376-164925$ & $172751-329850$ & $86376-164925$ & $86351-164900$ \\
\hline 32 & $164926-209425$ & $329851-418850$ & $164926-209425$ & $164901-209400$ \\
\hline 35 & $209426-523600$ & $418851-628300$ & $209426-314150$ & $209401-523600$ \\
\hline 37 & powyżej 523 600 & powyżej 628 300 & powyżej 314 450 & powyżej 523 600 \\
\hline
\end{tabular}

Źródło: (Internal Revenue Service).

Wszelkie straty mogą zostać wykorzystane do zmniejszenia podstawy podatku dochodowego o maksymalnie 3000 USD. Jeżeli kwota straty przekracza ten próg, może zostać przeniesiona na kolejne lata podatkowe. Posiadanie kryptowaluty przez okres dłuższy niż rok wiąże się ze znacznie niższym podatkiem od 
długoterminowych zysków kapitałowych wynoszących w roku podatkowym 2021 odpowiednio $0 \%, 15 \%$ lub $20 \%$ w zależności od statusu podatnika (por. tabela 3.5 ).

Tabela 3.5. Stawki podatku od długoterminowych zysków kapitałowych w USA w 2021 roku (w \$)

\begin{tabular}{|l|c|c|c|}
\hline \multicolumn{1}{|c|}{ Status } & $\mathbf{0 \%}$ & $\mathbf{1 5 \%}$ & $\mathbf{2 0 \%}$ \\
\hline Rozliczenie samodzielne & do 40400 & $40401-445850$ & powyżej 445850 \\
\hline Rozliczenie wspólne z małżonkiem & do 80800 & $80801-501600$ & powyżej 501600 \\
\hline Małżonkowie rozliczający się osobno & do 40400 & $40401-250800$ & powyżej 250 800 \\
\hline Głowa rodziny & do 54100 & $54101-473750$ & powyżej 473750 \\
\hline
\end{tabular}

Źródło: (Internal Revenue Service).

\section{Japonia}

W Japonii handel kryptowalutami, ich wydobycie, dochody z pożyczki w kryptowalucie lub inne dochody związane $\mathrm{z}$ wirtualnymi walutami są klasyfikowane jako dochody różne (Ustawa nr 62, 2016), podlegające stawce podatku do 55\%. W porównaniu ze stawką podatku od zysków kapitałowych, która w Japonii wynosi $20 \%$ (KPMG, 2021), zyski z kryptowalut są zatem bardzo wysoko opodatkowane. To zniechęca osoby fizyczne i firmy do ich prawidłowego ewidencjonowania w zeznaniach podatkowych. Warto zaznaczyć, że nierezydenci są opodatkowani zryczałtowaną stawką podatku $20 \%$ od dochodu, który muszą zapłacić po opuszczeniu Japonii. Stawki podatkowe różnią się w zależności od wysokości osiągniętego dochodu z transakcji kryptowalutowych w poprzednim roku (por. tabela 3.6). Warte podkreślenia jest to, że podane w tabeli stawki nie uwzględniają jeszcze stawki podatku liniowego $10 \%$ od dochodu, który jest płacony niezależnie.

Tabela 3.6. Opodatkowanie kryptowalut w Japonii w 2021 roku

\begin{tabular}{|c|c|}
\hline Dochód w JPY & Stawka (\%) \\
\hline Mniej niż $1,95 \mathrm{mln}$ & 5 \\
\hline $1,95 \mathrm{mln}-3,3 \mathrm{mln}$ & 10 \\
\hline $3,3 \mathrm{mln}-6,95 \mathrm{mln}$ & 20 \\
\hline $6,95 \mathrm{mln}-9 \mathrm{mln}$ & 23 \\
\hline $9 \mathrm{mln}-18 \mathrm{mln}$ & 33 \\
\hline $18 \mathrm{mln}-40 \mathrm{mln}$ & 40 \\
\hline $40 \mathrm{mln}$ i więcej & 45 \\
\hline
\end{tabular}

Źródło: (NTA). 
Obecnie japońskie organy podatkowe mają dość duże problemy z podmiotami uchylającymi się od zobowiązań podatkowych z tytułu handlu kryptowalutami. W związku z tym w Japonii planuje się reformę podatkową, zgodnie z którą kryptowaluty staną się ,,aktywami kryptograficznymi”, którymi będzie można obracać na legalnych i regulowanych giełdach. Prawdopodobnie nadchodząca reforma podatkowa, zgodnie z którą stawki opodatkowania kryptowalut mają być bardziej zbliżone do stawek podatku dochodowego i podatku od zysków kapitałowych, mogłaby skłonić podatników do przestrzegania przepisów podatkowych (McClure, 2021).

\subsection{Transakcje na rynku kryptowalut w kontekście podatku dochodowego w Polsce}

Handel kryptowalutami należy uznać za dość specyficzny z punktu widzenia regulacji podatkowych w Polsce. Zmiany w tym zakresie pojawiły się w naszym kraju w 2019 roku. W dniu 1.01.2019 roku weszła w życie ustawa z 23.10.2018 r. o zmianie ustawy o podatku dochodowym od osób fizycznych, ustawy o podatku dochodowym od osób prawnych, ustawy - Ordynacja podatkowa oraz niektórych innych ustaw, która spowodowała istotne zmiany w opodatkowaniu obrotu kryptowalutami podatkiem dochodowym od osób fizycznych oraz podatkiem dochodowym od osób prawnych. Przed wskazaną nowelizacją w polskim prawie podatkowym nie obowiązywały szczególne reguły opodatkowania w tym zakresie. Zgodnie z nowymi przepisami prawa podatnicy, którzy odnotowują zysk na handlu kryptowalutami, a także dokonują rozliczeń w walucie wirtualnej, powinni postępować zgodnie z określonymi zasadami i dokumentować transakcje według ustalonych wytycznych. Podatnik jest zobowiązany rozliczyć w rocznej deklaracji podatkowej przychody i koszty poniesione z tytułu transakcji kryptowalutami. Obie te kategorie rozlicza się w deklaracji PIT-38 w źródle kapitały pieniężne.

Zgodnie z ustawą nie należy łączyć przychodów i kosztów z pozostałymi kwotami w ramach całej grupy kapitałów pieniężnych. Oznacza to, że:

- przychody z tytułu zbycia kryptowalut mogą być sumowane tylko i wyłącznie z pozostałymi przychodami z tytułu zbycia kryptowalut,

- koszt poniesiony na nabycie kryptowalut nie może być sumowany z kosztami nabycia akcji, udziałów itd. znajdujących się w grupie kapitałów pieniężnych,

- dochód będący podstawą opodatkowania, czyli różnica przychodów i kosztów, może być rozliczana tylko i wyłącznie wraz z pozostałymi dochodami z wymiany kryptowalut, 
- nadwyżka kosztów ponad wartość przychodu w ujęciu rocznym nie łączy się $\mathrm{z}$ taką samą nadwyżką występującą w pozostałych kapitałach pieniężnych i jest przenoszona do rozliczenia na następny rok podatkowy.

Zdarza się, że podatnicy w ramach prowadzonej działalności gospodarczej wykonują transakcje, korzystając w tym celu z kryptowalut. Mimo że rozliczenie odbywa się w ramach działalności, ujęcie podatkowe transakcji powinno zawsze skutkować ustaleniem przychodu lub kosztu z tytułu kupna/sprzedaży kryptowaluty poza działalnością gospodarczą. W związku z powyższym:

- Nie ma możliwości kupna/sprzedaży kryptowaluty w ramach działalności gospodarczej i rozliczenia jej z przychodami/kosztami, ograniczając tym samym wartość dochodu firmy w danym okresie.

- Podatek od kryptowalut wynosi 19\% podstawy opodatkowania, czyli 19\% przychodu po odjęciu od niego kosztów jego uzyskania. Kwoty podstawy opodatkowania nie można obniżać o wartość ulg i odliczeń podatkowych. Zobowiązanie podatkowe od transakcji kryptowalutowych należy uiścić na koniec roku w deklaracji rocznej; reguluje się wyłącznie roczny podatek od całości rozliczeń.

Jeśli podatnik posiada różne rodzaje przychodów kapitałowych, z których jednym są kapitały pieniężne, to nie ma konieczności wysyłania wielu osobnych deklaracji PIT-38. Podatek jest płatny nie później niż do końca kwietnia roku następującego po rozliczanym roku podatkowym. Może się zdarzyć, że podatnik opłaca podatek wykazany w PIT-38 z kilku tytułów - inaczej niż w zakresie łączenia dochodów, samej zapłaty podatku można dokonać jednym łącznym przelewem, na całą kwotę wynikającą z deklaracji PIT-38.

Należy zaznaczyć, że za przychody z zysków kapitałowych uważa się przychody z wymiany waluty wirtualnej na środek płatniczy, towar, usługę lub prawo majątkowe inne niż waluta wirtualna lub z regulowania innych zobowiązań walutą wirtualną. Istotne są zatem przychody ze sprzedaży waluty na giełdzie - wartość przychodu to wartość otrzymanych $\mathrm{w}$ zamian za kryptowaluty środków pieniężnych po przeliczeniu ich na polskie złote po kursie średnim NBP z dnia roboczego poprzedzającego datę uzyskania przychodu. Ponadto jako przychody uznaje się także zamianę na towar, usługę lub inne prawo majątkowe w przypadku umów barterowych z rozliczeniem kryptowalutą. Wówczas strony powinny ustalić wartość świadczenia.

Zgodnie z ustawą datą rozpoznania przychodu jest data uznania środków na rachunku bankowym podatnika na giełdzie wymiany kryptowalut. Przychodu zatem nie należy rozpoznawać dopiero w momencie wyprowadzenia środków $\mathrm{z}$ rachunku wirtualnego na rachunek bankowy podatnika. Kolejną ważną kwestią jest to, że w momencie uzyskania przychodów nie ma konieczności rozliczania różnic kursowych. W efekcie bardzo często dochodzi do wypłaty w walucie obcej 
po zamianie kryptowaluty na wartości pieniężne, a dopiero później - do zamiany środków w tej walucie - na walutę polską. Należy w tym miejscu zaznaczyć, że przychodu nie wykazuje się w związku z transakcją zamiany jednej kryptowaluty na inną kryptowalutę. Transakcja pozostaje neutralna podatkowo aż do momentu, gdy któraś kolejna z wymienionych kryptowalut zostanie sprzedana albo zostanie zamieniona na towar/usługę. W tym przypadku dochodzi do rozliczenia podatkowego transakcji.

Kolejną kategorią wymagającą omówienia są koszty. Zgodnie z ustawą za koszty uzyskania przychodów uznaje się:

- wyłącznie bezpośrednie koszty nabycia kryptowaluty, na przykład koszt nabycia, prowizję;

- pośrednie i bezpośrednie koszty zbycia kryptowaluty, na przykład ogłoszenia sprzedaży, prowizję od sprzedaży (Ustawa z dnia 23 października 2018).

Koszty uzyskania przychodów należy uwzględnić w tym roku podatkowym, w którym zostały poniesione. W sytuacji odpłatnego nabycia kryptowaluty od zidentyfikowanego kontrahenta liczy się dzień wystawienia przez kontrahenta faktury, rachunku lub innego dokumentu, a w przypadku jego braku - dokumentu wewnętrznego. Wyjątkiem jest sytuacja, gdy płatność nastąpi przed tą datą - wówczas istotna jest data płatności. W przypadku odpłatnego nabycia kryptowaluty od anonimowego kontrahenta momentem wystąpienia kosztu jest dzień obciążenia rachunku.

Bardzo często zdarza się, że w transakcjach na giełdach waluty wirtualnej występuje brak danych sprzedawcy - typowe jest wtedy korzystanie z tzw. dokumentów wadliwych. Koszt identyfikuje się wówczas na podstawie dokumentów zawierających łącznie następujące informacje:

- rodzaj kryptowaluty,

- nazwę,

- kod/oznaczenie identyfikujące kryptowalutę,

- ilość, datę i sposób nabycia,

- koszt nabycia,

- potwierdzenia przelewów bankowych na rachunek giełdy kryptowalut,

- wyciągi elektroniczne z giełd,

- arkusze potwierdzające dokonanie transakcji,

- wiadomości elektroniczne lub generowane w ramach kont giełdy potwierdzające transakcje (Ustawa z dnia 23 października 2018).

Dla celów podatkowych nie ma znaczenia rodzaj kryptowaluty - koszty poniesione z tytułu zakupu jednej kryptowaluty można rozliczać w deklaracji PIT z przychodem ze sprzedaży innej. Koszty należy wykazać nawet wtedy, gdy nie uzyskano w danym roku żadnych przychodów. Może wystąpić sytuacja, gdy PIT-38 będzie zawierać wykazane koszty nabycia kryptowaluty i brak jakichkolwiek przychodów 
z tytułu ich sprzedaży. W kolejnym natomiast roku dojdzie do wykazania samej wartości przychodu ze sprzedaży - bez ustalenia z tego tytułu kosztów.

\subsection{Analiza SWOT opodatkowania kryptowalut}

Po zaprezentowaniu rozwiązań podatkowych dotyczących kryptowalut w wybranych krajach można przejść do podsumowania i analizy SWOT opodatkowania tych walut. SWOT jest metodą analizy procesów zachodzących na rynku. Umożliwia ona zidentyfikowanie mocnych i słabych stron oraz szans i zagrożeń płynących z otoczenia. Określa pozycję badanego obiektu na rynku oraz możliwe kierunki rozwoju. Jest podstawą do budowania planów strategicznych. Analiza SWOT jest ważna w przypadku opodatkowania kryptowalut. Pozwala ona bowiem na spojrzenie na tę problematykę w kontekście dalszego rozwoju rynku kryptowalut, dla którego kwestie prawne i podatkowe są bardzo ważne, co dostrzega coraz większa rzesza rządzących z różnych krajów świata. Najważniejsze kwestie dotyczące analizy SWOT związane z opodatkowaniem kryptowalut przedstawiono poniżej. Dla porządku w sposób syntetyczny zawarto je także w tabeli 3.7.

Tabela 3.7. Analiza SWOT opodatkowania kryptowalut

\begin{tabular}{|c|c|}
\hline Mocne strony & Slabe strony \\
\hline $\begin{array}{l}\text { - dobrze zorganizowany rynek transakcji } \\
\text { kryptowalutami } \\
\text { - wiele podobieństw do już istniejących opo- } \\
\text { datkowanych instrumentów finansowych } \\
\text { regulacja wyłącznie przez procesy rynkowe }\end{array}$ & $\begin{array}{l}\text { - niejasne i skomplikowane przepisy podatko- } \\
\text { we dotyczące obrotu walutami wirtualnymi } \\
\text { - brak jednolitych zasad opodatkowania } \\
\text { w różnych krajach } \\
\text { - ograniczona edukacja użytkowników kryp- } \\
\text { towalut w kontekście ich opodatkowania }\end{array}$ \\
\hline Szanse & Zagrożenia \\
\hline $\begin{array}{l}\text { potencjalne wysokie wpływy do budżetu } \\
\text { z tytułu opodatkowania kryptowalut } \\
\text { harmonizacja przepisów dotyczących opo- } \\
\text { datkowania kryptowalut na świecie } \\
\text { uproszczenie przepisów podatkowych doty- } \\
\text { czących walut wirtualnych }\end{array}$ & $\begin{array}{l}\text { - możliwość szerokiego wykorzystania przez } \\
\text { świat przestępczy } \\
\text { - powstawanie „rajów podatkowych” dla użyt- } \\
\text { kowników kryptowalut } \\
\text { - wysokie prawdopodobieństwo ataków hac- } \\
\text { kerskich na istotne węzły systemu }\end{array}$ \\
\hline
\end{tabular}

Źródło: opracowanie własne.

\section{Mocne strony}

Do mocnych stron systemu opodatkowania kryptowalut należą:

- dobrze zorganizowany rynek transakcji kryptowalutami - zbudowany na nowoczesnych technologiach rynek wymiany walut wirtualnych wpływa na dostęp do danych dobrej jakości przez organy podatkowe; 
- wiele podobieństw do już istniejących opodatkowanych instrumentów finansowych $-\mathrm{z}$ pewnością ułatwia to konstrukcję przepisów podatkowych opartych na rozwiązaniach dotyczących rynków i giełd tradycyjnych instrumentów finansowych (takich jak akcje czy waluty tradycyjne), które już sprawdziły się w praktyce;

- regulacja wyłącznie przez procesy rynkowe - w praktyce żadne państwo ani organizacja nie ma możliwości odgórnego zwiększenia podaży, nie istnieją żadne instrumenty administracyjne, które mogłyby wpływać na dewaluację kursu kryptowaluty.

\section{Słabe strony}

Do słabych stron opodatkowania kryptowalut należy z kolei zaliczyć:

- niejasne i skomplikowane przepisy podatkowe dotyczące obrotu walutami wirtualnymi - często mało precyzyjne i trudne dla podatników przepisy dotyczące kryptowalut mogą prowadzić do licznych błędów w rozliczeniach podatkowych, a także pokusy uchylania się od opodatkowania;

- brak jednolitych zasad opodatkowania w różnych krajach - wpływa na chęć uzyskania optymalizacji podatkowej i poszukiwania przez podatników rozwiązań najkorzystniejszych i najprostszych poza granicami swojego państwa i uszczuplenie jego wpływów podatkowych;

- ograniczona edukacja użytkowników kryptowalut w kontekście ich opodatkowania - w wielu przypadkach, ze względu na bardzo ograniczone edukowanie w zakresie opodatkowania transakcji kryptowalutowych, część podatników nie jest świadoma wystąpienia $\mathrm{w}$ ich przypadku obowiązku podatkowego.

\section{Szanse}

Wśród szans związanych z opodatkowaniem kryptowalut wyróżnić można:

- potencjalnie wysokie wpływy do budżetu z tytułu opodatkowania kryptowalut - w przypadku upowszechnienia opodatkowania transakcji kryptowalutowych, ze względu na ogromny rozmiar i potencjał tego rynku, może się to wiązać ze znaczącym wzrostem wpływów budżetowych z tytułu transakcji walutą wirtualną w przyszłości;

- korzyści z harmonizacji przepisów dotyczących opodatkowania kryptowalut na świecie - wprowadzenie jednolitych przepisów oraz ich uporządkowanie w większości krajów świata wpłynie na poczucie sprawiedliwości społecznej i lepszą ściągalność podatków z tego tytułu; 
- uproszczenie przepisów podatkowych dotyczących walut wirtualnych obecnie przepisy podatkowe w zakresie opodatkowania kryptowalut są często zawiłe i kłopotliwe z punktu widzenia podatnika, w przypadku ich uproszczenia efektem może być mniejsza chęć do uchylania się od opodatkowania.

\section{Zagrożenia}

Z kolei do najpoważniejszych zagrożeń związanych z opodatkowaniem kryptowalut należy wymienić:

- możliwość szerokiego wykorzystania kryptowalut przez świat przestępczy - wysoki stopień anonimowości użytkowników, szczególnie tych niedokonujących wymiany kryptowalut na waluty krajowe, może zachęcać do wykorzystania systemu w celach niezgodnych z prawem; brak szczegółowej kontroli administracyjnej, w tym podatkowej, nad transferowanymi środkami wpływa również na wysokie prawdopodobieństwo wykorzystania walut wirtualnych do tzw. prania brudnych pieniędzy.

- powstawanie „rajów podatkowych” dla użytkowników kryptowalut - istnieje zagrożenie, że władze niektórych krajów nie będą chciałby współpracować w kwestii harmonizacji opodatkowania kryptowalut i stworzą dobre warunki do oszustw podatkowych i uchylania się od opodatkowania;

- wysokie prawdopodobieństwo ataków hakerskich na istotne węzły syste$\mathrm{mu}$ - istnieje wysokie prawdopodobieństwo ataków hakerskich na niektóre elementy systemu, co może także spowodować nieścisłości w kwestii zobowiązań podatkowych.

\subsection{Podsumowanie}

Obrót kryptowalutami i jego konsekwencje podatkowe nie zostały zharmonizowane i w obszarze podatków dochodowych rozstrzygające pozostają zasady obowiązujące w poszczególnych państwach. Analizując poszczególne rozwiązania, możemy zauważyć wiele podobieństw - preferowane są inwestycje długoterminowe, które są opodatkowane stawkami zdecydowanie niższymi niż działania spekulacyjne. Problemem w wybranych w tym rozdziale krajach jest z kolei nieprzyjazna dla podatników konieczność szczegółowej dokumentacji przeprowadzonych transakcji, która często powoduje niechęć podatników do rzetelnego jej prowadzenia, a co za tym idzie - znaczących strat dla budżetów krajowych.

Celem przyjętych w Polsce od początku 2019 roku rozwiązań dotyczących opodatkowania kryptowalut było przede wszystkim zachowanie prostoty. Nowo 
wprowadzony reżim opodatkowania obrotu walutami wirtualnymi odpowiada na kluczowe wątpliwości interpretacyjne, z którymi musieli się mierzyć podatnicy przed tą datą, co zostało także docenione przez praktyków. Obecnie obowiązujące przepisy prawa dają odpowiedź na pytania dotyczące kwalifikacji przychodu z obrotu kryptowalutami do właściwego źródła przychodów, sposobu rozliczania kosztów uzyskania przychodów czy też zdefiniowania skutków podatkowych zamiany kryptowalut lub zapłaty nimi za towary lub usługi. Rozwiązania w obu ustawach o podatkach dochodowych są analogiczne w zakresie zasad ustalania przychodów, kosztów oraz dochodów (strat). Nowe przepisy wprowadzają porządek w stosunku do podatkowych kwestii obrotu kryptowalutami, pozwalają osiągnąć kompromis między interesem inwestorów a Skarbem Państwa.

$\mathrm{Z}$ pewnością $\mathrm{z}$ tego powodu, a także $\mathrm{z}$ innych powodów ukazanych $\mathrm{w}$ przeprowadzonej w rozdziale analizie SWOT tematyka opodatkowania transakcji kryptowalutowych jest niezwykle rozwojowa i jeszcze długo będzie ciekawym obszarem do dalszych badań.

\section{Bibliografia}

Bandura, J. (2021). Największe giełdy kryptowalut na świecie. Pobrane z https://tradersarea.pl/najwieksze-gieldy-kryptowalut-na-swiecie

Będowska-Sójka, B. i Kliber, A. (2021). Is there one safe-haven for various turbulences? The evidence from gold, Bitcoin and Ether. North American Journal of Economics and Finance, 56, 1-12.

Będowska-Sójka, B., Hinc, T. i Kliber, A. (2020). Volatility and liquidity in cryptocurrency markets - The causality approach. W: K. Jajuga, H. Locarek-Junge, L. T. Orłowski, ... K. Stachr (Eds.), Contemporary trends and challenges in finance: Proceedings from the 5th Wroclaw International Conference in Finance (s. 31-43).

Brzeszczyński, J., Gajdka, J. i Schabek, T. (2020). Bitcoin as a new currency. Folia Oeconomica Stetinensia, 20(2), 49-65.

Chatham, M. D. i Duncan, T. K. (2020). Taxation as a barrier to blockchain innovation. Taxation of Investments, 38, 3-21.

Chen, W., Xu, H., Jia, L. i Gao, Y. (2021). Machine learning model for Bitcoin exchange rate prediction using economic and technology determinants. International Journal of Forecasting, 37, 1, 28-43.

Coinmap.Mapa. Pobrane z https://coinmap.org/view/\#/map/51.86716406/19.46777344/9/ undefined

Conlon, T. i McGee, R. (2020). Safe haven or risky hazard? Bitcoin during the Covid-19 bear market. Finance Research Letters, 35.

De Hoon, I. (2021). Germany \& Portugal. Two amazing bitcoin tax havens!. Pobrane z https://nomoretax.eu/germany-portugal-two-amazing-bitcoin-tax-havens

Einkommensteuergesetz z dnia 16.10.1934 roku wraz z późniejszymi zmianami. 
Fryc, J. (2016). Kryptowaluta coraz bardziej popularna. Gdzie zapłacisz bitcoinem w Polsce. Pobrane z https://businessinsider.com.pl/finanse/kryptowaluty/bitcoin-gdzie-mozna-zaplacic-kryptowaluta/yw7hrfz

Griffin, J. M. i Shams, A. (2020). Is bitcoin really untethered?. Journal of Finance, 75, 1913-1964.

Guégan, D. i Renault, T. (2021). Does investor sentiment on social media provide robust information for Bitcoin returns predictability?. Finance Research Letters, 38.

Internal revenue service. Virtual currencies. (2021). Pobrane 25 maja $2021 \mathrm{z} \mathrm{https://www.}$ irs.gov/businesses/small-businesses-self-employed/virtual-currencies

Investing.com. Wszystkie kryptowaluty. Pobrane 25 maja $2021 \mathrm{z}$ https://pl.investing.com/ crypto/currencies

Kowalczyk, M. i Wilga, D. (2019). Blockchain - perspektywy wdrożeń w sektorze publicznym. Collegium of Economic Analysis Annals, 56, 121-131.

KPMG. (2021). Japan - Taxation of international executives. Pobrane $\mathrm{z}$ https://home. kpmg/xx/en/home/insights/2021/09/japan-taxation-of-international-executives.html

Leech, I. (2021). Crypto Tax 2021: A complete US guide. Pobrane z https://www.coindesk. com/crypto-tax-2021-guide

Markowski, K. (2019). Kryptowaluty. Powstanie - Typologia - Charakterystyka. Civitas et Lex, 3, 70-82.

Marszałek, P. (2019). Kryptowaluty - pojęcie, cechy, kontrowersje. Studia Biura Analiz Sejmowych Kancelarii Sejmu, 1(57), 105-125.

McClure, Z. (2021). Crypto taxes in Japan. Pobrane z https://tokentax.co/guides/crypto-taxes-in-japan/

NTA. Individual Income Tax. Pobrane z https://www.nta.go.jp/english/taxes/individual/ index.htm

Perez, K. i Urbaniak, M. (2013). Bitcoin - wirtualny eksperyment czy waluta przyszłości? Ruch Prawniczy, Ekonomiczny i Socjologiczny, 4, 163-180.

Pitta, R. (1999). Requiem for a bright idea. Pobrane z https://www.forbes.com/ forbes/1999/1101/ 6411390a.html\#873fdc4715f6

Rosik, P. (2021). Sprawdzamy ile jest bitcoinów, ile można jeszcze wykopać oraz ile będzie w obrocie. Pobrane z https://strefainwestorow.pl/artykuly/bitcoin/20210122/bitcoin-podaz-inflacja

Scharnowski, S. (2021). Understanding Bitcoin liquidity. Finance Research Letters, 38.

Shahzad, S. J. W., Bouri, E., Roubaud, D. i Kristoufek, L. (2020). Safe haven, hedge and diversification for G7 stock markets: Gold versus bitcoin. Economic Modelling, 87, 212-224.

Sławiński, A. (2020). Will IT technologies and globalisation change the mechanism of money creation?. Public Governance / Zarzadzanie Publiczne, 50(4), 5-14.

$\mathrm{Su}, \mathrm{Ch}-\mathrm{W} .$, Qin, M., Tao, R. i Umar, M. (2020). Financial implications of fourth industrial revolution: Can bitcoin improve prospects of energy investment?. Technol Forecast Soc Change.

Su, Ch.-W., Qin, M., Tao, R., Umar, M., Shao, X.-F., Albu, L. L. (2020). Can Bitcoin hedge the risks of geopolitical events?. Technological Forecasting and Social Change, 159.

Taxfix. Bitcoin and Tax: Cryptocurrencies in your tax return. Pobrane z https://taxfix.de/ en/finance-tips-in-germany/bitcoin-and-tax-cryptocurrencies-in-your-tax-return/ 
Ustawa z dnia 8 października 2009 r. o podatku dochodowym wraz z późniejszymi zmianami (Federalny Dz.U. I, s. 3366, 3862).

Ustawa o zmianie części ustawy bankowej oraz innych ustaw w celu dostosowania do zmian $\mathrm{w}$ środowisku dokonywanych przez technologie teleinformatyczne. Ustawa $\mathrm{nr}$ $62 \mathrm{z} 2016 \mathrm{r}$.

Ustawa z dnia 23 października 2018 r. o zmianie ustawy o podatku dochodowym od osób fizycznych, ustawy o podatku dochodowym od osób prawnych, ustawy - Ordynacja podatkowa oraz niektórych innych ustaw (Dz. U. z 2018 r., poz. 2193).

Włosik, K. (2019). Liquidity of bitcoin - insights from Polish and global markets. Ruch Prawniczy, Ekonomiczny i Socjologiczny, 81(3), 167-183. 